Language

Te^

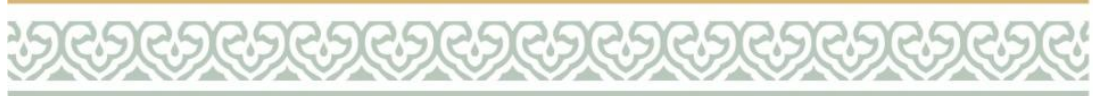

Язык

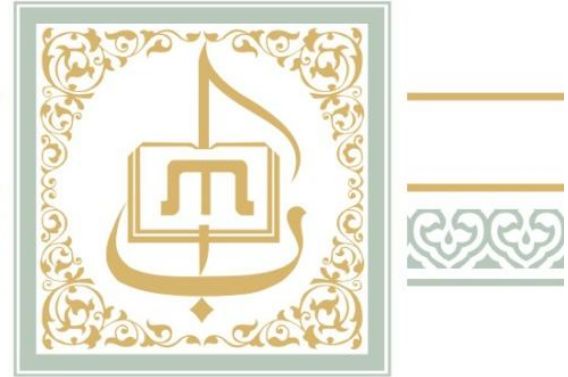

DOI: $10.26907 / 2311-2042-2021-16-1-7-16$

\title{
TOPONYMIC PARALLELS OF TATARSTAN AND AZERBAIJAN
}

\author{
Arzu Idris gizi Huseynova, \\ Institute of Linguistics named after Nasimi, \\ National Academy of Sciences of Azerbaijan, \\ 31 Huseyn Javid Str., Baku, \\ arzu_56@mail.ru. \\ Gulfiya Kamilovna Khadieva, \\ Kazan Federal University, \\ 18 Kremlevskaya Str., Kazan, 420008, Russian Federation, \\ gul-khadieva@yandex.ru.
}

\begin{abstract}
The article examines parallel Turkic toponyms found in the territories of Tatarstan and Azerbaijan, as they can shed light on the history of the Turkic-speaking peoples' settlement in these vast territories. Nowadays, when the origin of the toponyms and the processes of their formation over a long historical period are being clarified, their distribution area is of current interest. As toponyms are our cultural heritage, they enable us to make a mental journey to the historical origins of our people. Parallel toponyms, like puzzles, help recreate the map of the settlement and formation of such peoples as Azerbaijanis, Tatars, Bashkirs, Kirghiz, Kumyks, etc. Further studies of parallel toponyms will shed light on many onomastics issues. The studied toponymic data prove the complexity of the Turkic peoples' migration routes in the course of global historical processes across vast territories.
\end{abstract}

Key words: parallel ethnotoponyms, binary correlates, semantic field, lexeme, plurality affix, global.

Modern Turkic toponymy has rich factual material on its varieties and its theoretical and methodological potential, based on the achievements of general linguistics and onomastics. This is largely due to the widespread use of Turkic names in the vast geospace of Eurasia. The area of distribution of Turkic toponymic names is quite large and stretches "north as far as the shores of the Arctic Ocean, east as far as Transbaikalia and the Great
Khingan, west as far as Eastern and Southern Europe, and south as far as Tibet, India, Karakorum and North Africa" [Murzaev, p. 37].

The research object of this article is parallel toponyms of Tatarstan and Azerbaijan.

Türkic toponymic parallels are found on a vast territory inhabited by various Türkic-speaking peoples. Fazlallah Rashidaddin's "Jami-attavarikh" describes the Tatar tribe in the following 
way: "Their name has been known in the world since ancient times. Numerous branches have split off from them. That tribe <consisted > of seventy thousand houses <or families>. Because of <their> extraordinary greatness and honorable position, other Turkic clans, although different in their categories and names, became known under their name and all of them were called Tatars" [Rashid-addin].

The Türkic toponymic system has its own general patterns, which were noted and are still noted by many researchers of toponymy in the Türkicspeaking regions. Thus, L. G. Guliyeva writes that "the fact that languages have parallel names for one object, as well as names of binary opposition for different objects, is an onomastic universal" [Gulieva, p. 175].

Correlated binary data are found in the toponymy of Tatarstan and on the territory of other Turkic-speaking regions. Such a phenomenon occurs quite often in toponymy. Transferring a name from one object to another is a universal way of forming new names in the oikonymy of any language.

The new oikonym component introduces certain information about the place of origin and the size of the settlement. For example: Oly Koek (Big Kuyuk), Keche Көек (Small Kuyuk), Iugary Mataska (Upper Meteska), TYban Mataska (Lower Meteska). Over time, new villages separated from the main village and were usually called the same name as the main village, but with the addition of some defining words: iske 'old', urta 'medium', oly 'big' - keche 'small', 'smaller', tybon 'lower' yugars 'upper'. The pairs of words iugary - tyban, oly - keche are frequently used lexemes in the oikonymy of Tatarstan. "The reason for this phenomenon lies in the essence of oikonymy. One of its features is the basic oikonymic objects that can serve as a foundation for the formation of new objects, maternal or filial ones" [Kamalov, p. 98]. During the formation of subsidiary settlements, maternal villages occupied an important place in the social and economic system of the region.

Among orientational epithets, iugary and tyban prevail, being among the most popular spatial indicators: Iugary Matoska (Upper Meteska) - TYbən Mataska (Lower Meteska), Iugary Disha (Upper Oisha) - TYban Disha (Lower Disha), Iugary At (Upper At) - TY ban Aty (Lower Aty).

Oikonyms of the type Iske Kyrlai (Old)-Keche Kyrlai (Small), Oly Mayger (Big) - Keche Məuger (Small), Oly Mataska(Big) - Iugary Mataska (Upper), Iske Mui (Old Mui) - Keчe Myü (Small Mui), Iske Shyrdan (Old Shyrdan)- Oly Shyrdan
(Big Shyrdan), which are the elements of binary oppositions, form peculiar correlative pairs where first components cannot be placed in opposition. In the concise reference book "AdministrativeTerritorial Division of the Republic of Tatarstan" (1992), the word ящза is found in 110 names. In the oikonymy of the region, certain oppositions are paired with a zero form. This is explained by the place of the base settlement in the socio-economic life of a certain territory: Zur Elga (Great River) Елга, Iske Tobək (Old Region) - Tөbək. Of interest are the names with a basic oikonym. These oikonyms led to the emergence of new components: Kazile = Iugary Kazile (Upper Kazile) Urta Kazile (Middle Kazile) - TYbon Kazile (Lower Kazile); Әisha = Iugary Әisha (Upper Әisha) Urta Oisha (Middle Oisha) -TYban Đisha (Lower Oisho).

The concepts of iugary 'upper', urta 'middle', and $t_{Y} b a n$ 'lower' in the composition of oikonyms serve as a guide of a vertical position in space. The object closest to the guiding point is designated by the concept of 'lower' - tyban and the farthest point is the object, expressed by the concept of 'upper' - iugary The reason, apparently, is that some objects, located in the lower parts of rivers, mountains, etc., were developed earlier than the territories, located in their upper part, along with laying a route along the river [Khadieva, pp. 181182].

Binary correlates are also widespread in Azerbaijan toponymy; further, we will provide examples of the binary correlates usage in the Agstafa and Gazakh regions of Azerbaijan, which were formed using the components yuxarl 'upper', aşağl 'lower', orta 'middle': Yuxarı Salahl, Aşağı Salahl, Orta Salahll.

G. F. Sattarov singled out the village of Iske Onale (Old Yenali) in the Apastovsky district of Tatarstan. He associated its etymology with the word инал, meaning the estate of a noble Türk. According to the scientist, the local pronunciation of the word инал (the Apastovo dialect) is anale $<$ inal ille $>$ inalle $>$ anale; the middle dialect of the Tatar language is characterized by the transition of the vowels $u>\partial$. To substantiate his hypothesis, G. F. Sattarov cites the following fact: near the village of Tarkhan in the Tetyushsky region, a gravestone was found, dated 1320, belonging to the Bulgarin Mir-Ibrahim Inal. The researcher provides examples from the Ancient Türkic dictionary: inal öz, inal quç, terbi inal, inal qayan [Sattarov, p. 86]. 
There is the village of Eynalli on the territory of the Agstafa region in Azerbaijan. In the essay "Tarikh-e-alem arai-i Abbasi" by the medieval chronicler Iskender Munshi, the Azerbaijani tribes of the Middle Ages are listed: the Abdallu tribe, one of the branches of the famous Kyzylbash tribe Shamlu, which had an olke (ölkə) in Mugan, and the Inallu tribe, another branch of Shamlu near Ardebil, Shagagi" [Rakhmani, p. 121]. After the collapse of the Seljuk state on the territory of Asia Minor, the Inal, Karaman, Zulkadar, Tarakli, Bagadurly, and Shamlu tribes became known. Thus, with the migration of the Oguz tribes, Oguz place names appeared in large territories. On the territory of South Azerbaijan in Iran, the toponym of Ainally (Aynalli) has been preserved. In his work "A Letter to the Yakut Intelligentsia", the Yakut educator and the founder of Yakut literature, A. E. Kulakovsky, back in 1912, mentioned the number of Aynalli residents, living in the Yakut region: "Aynalar - 1130 people" [Kulakovskii, p. 117]. B. A. Budagov cites the fact from the "Caucasian Calendar" concerning the existence of the toponym Aynalli in western Azerbaijan, the village of Aynalli, which was included into the fourth police station of the Echmiadzin district and was plundered and destroyed by the Armenians in 1918 [Budaqov, p. 154].

In the Jebrail, Gubadli, and Zangelan regions of Nagorno-Karabakh, the Republic of Azerbaijan, we find the oikonym Tamap - Tatar in the names of many villages, due to the Turkic tribes of the Tatars. There used to be the village of Tatarkand in the Barda region. Complex toponyms, formed with the help of the ethnonym Tatars, have survived in many regions of Azerbaijan. For example, in the Lachin region there are place names Tatar qaya (the Tatar rock) in the village of Hagnazar, and Tatarlılar yaylağı in the village of Alkhasly. In the Jebrail region, the toponym Tatar (Tatar düzü) is found in the village of Nüsüs. In the Zangelan region, the village of Vezhnali, there is the Tatar gorge (Tatar darasi). In the Gakh region, the village of Armudlu, there is the Tatar rock (Tatar qaya). There is the mud volcano Tatarmahlo in the Salyan region. In the Neftchala region, there is an oikonym of the same name. In the Shamkir region, we find the oikonym Tatarll.

The ethnotoponym Karatun, preserved in the name of the railway station and the village in Tatarstan, has its parallel in Azerbaijan - the village of Karadonlu, located in the Mugan steppe, which used to be a regional center until 1938. A kilometer off to the north-east of the village there are settlements dating back to the $9^{\text {th }}-13^{\text {th }}$ centuries A. D. The settlement of Karatun in Tatarstan had been known as Yenaleevo since 1647 and was founded in the $18^{\text {th }}$ century. According to one version, the etymology of the toponym goes back to the words kara 'black', tun 'dress', a monk's robe, a robe of fire worshipers. Among the Turkic tribes, there were the ones named after the color of headdresses and clothing. For example, Karapapahlilar is the name of one of the tribes in Azerbaijan. Karakalpaks, the name of the Turkic people, can also be attributed to such names. The black cowls were first mentioned in the Ipatiev Chronicle of 1146 and 1193, they took an active part in the life of Kievan Rus, as evidenced by the expression persistently repeated in this chronicle: "the whole land of Rus and black cowls" [Pletneva, p. 24]. Therefore, the black cowls were an important military force of the Kiev princes.

It is interesting to note that the toponym Kyrlai is found not only in the territory of the Turkic peoples. Many toponyms are found in Turkic literature and epos. Place names are a mirror image of the people's lyrical soul, of their aspirations. In the Kazakh epic "Koblandy-batyr", we find the names of the epic cities of Kyrly-Kala, Syrly-Kala: "Having taken by force, the cities of Kyrly-Kala and Syrly-Kala, Khan Kazan said boastfully: 'Look how well the city of Kyrly-Kala is fortified. The enemy will never approach my city of KyrlyKala"”.

Iap̧a Kyrlai (New Kyrlay) is a village in the Arsk region of the Republic of Tatarstan. To these toponyms we will add the toponym Kырыльь (Qlrll) of the Agstafa region in the Republic of Azerbaijan, it is the name of one of the ancient villages in Azerbaijan. On the territory of the village is the Raven Hill (Qargalar Tapasi), the site of the primitive people. The villagers are engaged in agriculture and cattle breeding. The toponym Kyrlaneny-Kırlannar (its official name is Kotovskoe) is the name of a Gagauz village on the Yalpug River in Moldova. The first texts in the Gagauz language were collected by V. A. Moshkov, a coordinator of the Archeology, History and Ethnography Society at Imperial Kazan University ("The Gagauz from the Bendery District", ethnographic essays and materials).

Let us consider the etymology of the toponym Kyrlai and the toponymic term Kyrla (Fields), discussed in the article of the same name by the researcher R. N. Garyaev, in whose opinion "the remains of the affix -ла/-лә were preserved in the Tatar and Bashkir terms кырла 'ridges of mountains', 
iaila 'plateaus' and in the toponymic name Ozyn kyrla (the name of an oblong mountain with four ridges in the Gafur region of the Republic of Bashkortostan). In conclusion, R. N. Garyaev put forward an assumption that the affix of plurality $-л a$ in the oikonym Kyrlai, "consists of the ancient general Altai indicator of collective plurality $-\pi$ and the indicator of indefinite plurality $-a$ [Gariaev, $\mathrm{p}$. 112].

The ethnotoponym, the village of Sabancha (Sabanchy), was located on the territory of the current Alekseevsky district in the Republic of Tatarstan. In the 1986 reference book, it is not mentioned. The Azerbaijani historian G. A. Geybullaev notes many places named Sabunchi in Azerbaijan: Mount Sabunchu, the ruins of Sabunchu in Western Azerbaijan, and the winter facilities in the Kars region in Turkey. The scientist refers to the Persian Shah Sultan Huseyn's decree of 1704 (1694-1722), in which among the listed 36 Turkic tribes, the Sabunchu tribe is mentioned [Geibullaev, p. 60]. Sabunchi is an urbantype settlement on the Absheron Peninsula. The Sabunchi district is one of 12 administrative districts of Baku. In the $18^{\text {th }}$ century, the village of Sabunchi was in the possession of Sardar Ashurbek Afshar, the ancestor of the Azerbaijani noble family of the Ashurbekovs. As for the etymology of the toponym Saban, let us refer to the works of researchers. As we know from F. F. Gafarova's research, the word saban has a wide semantic field with the main meaning plough, found in all sources. Let's list the six meanings of the word saban in some Turkic languages: Tatar, Bashkir, Kumyk, Kyrgyz: 1) plough; 2) fixed expressions: saban fat / arable land /; 3) in Kyrgyz: it is arable land / saban saluu - to be engaged in agriculture /; 4) in Kabardino-Balkarian: buday sabanla - a wheat field; 5) spring field work / saban chəche spring sowing; 6) in Tatar: spring crops / saban ashlygy - spring bread, saban uragy - the harvest of spring crops [Gafarova, p. 90]. In the "TurkishRussian Dictionary", the word saban is translated as a plough, kara saban - a wooden plough [Rybalchenko, p. 255]. It can be assumed that the place where farmers and ploughmen lived was called Sabancha in Tatarstan and SabunchiSabunchu in Azerbaijan. Since 1825, Sabunchi has become one of the main oil production areas in Absheron. In the late $19^{\text {th }}$ and early $20^{\text {th }}$ centuries, due to the rapid development of oil industry in the region, there was a large influx of workers to the oil fields from different parts of the vast Russian Empire in Sabunchu, among them were immigrants from the Volga region and many Tatars, whose descendants still live in the Republic of Azerbaijan. From 1724, Baku was populated by Kazan Tatars, Cheremis, and Chuvashes (about five thousand people), who were sent to Baku for shipbuilding work.

On the territory of Azerbaijan and Tatarstan there are place names Aktash - Agdash, Liaki (Aktash - Agdash, Lyaki). Aktash is a village in the Almetyevsk regionof the Republic of Tatarstan, which appeared three hundred years ago. The village of Aktash is also found in the Ulagan region of the Altai Republic in the Russian Federation. The village of Lyaki is located on the left bank of the Igana River in the Sarmanovsky district of Tatarstan, it has been known since 1691. At the beginning of the $20^{\text {th }}$ century, a church, a zemstvo school, and a water mill functioned in the village of Lyaki. There is a railway station and the village of Lyaki in the Agdash region of Azerbaijan. According to the "Caucasian Calendar for 1856", Lyaki was a village of the Agdash mahal, whose population was designated as Sunni Tatars [Kavkazskii kalendar' na 1856 god, p. 353]. In the Russian Empire, this was the name for the Turkic population of Azerbaijan in the $19^{\text {th }}$ century. In 1883 , the railway station named Lyaki was opened on the territory of the village. In addition to the village of Lyaki, there were also the villages of Iukhary Liaki (Upper Lyaki), Ashagy Liaki (Nizhny Lyaki), and Orta Liaki (Middle Lyaki). In the Azerbaijani language, the ашагы component is used to designate something lower, in contrast to

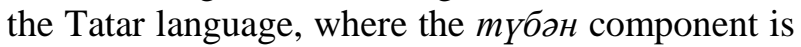
used. According to some studies, the etymology of the toponym Lyaki goes back to the Oguz tribe Lyak [Entsiklopedicheskii slovar' toponimiki Azerbaidzhana, p. 84].

In our opinion, many parallel toponyms and ethnotoponyms, including Iske Onale (Old Yenali), Каратун (Karatun), Sabancha (Sabancha), Kbipлай (Kyrlai), Aktash-Agdash (Aktash-Agdash), Ляки (Lyaki) of the Republic of Tatarstan, and their parallels found in Bashkortostan, Azerbaijan, South Azerbaijan (Iran), in Western Siberia, Turkey and other regions evidence complex ethnic processes associated with the movement and migration of Turkic tribes in different historical periods. Parallel Turkic place names, widespread on the territory of Eurasia and Asia Minor, indicate that the Turkic peoples, living in different historical periods, were engaged in state activities and trade, and took an active part in the life of these regions. 
Thus, the toponymic parallels, found in different territories, carry the most important information about the peoples, inhabiting a particular region. Such names do not appear by chance, their distant and close relationships do not raise doubts, because the peoples, accustomed to the names of a certain model, of a certain pronunciation, bring them to new places, leaving them in a new territory. They bear a historical connection of peoples in different eras.

\section{References}

Budaqov, B. Ә., Qeybullayev, Q. Ә. (1998). Ermanistanda Azarbaycan manşali toponimlarinin izahl lüğati [Explanatory Dictionary of Toponyms of Azerbaijani Origin in Armenia]. 452 p. Bak1, "Nafta-Press". (In Azerbaijani)

Entsiklopedicheskii slovar toponimiki Azerbaidzhana: $v 2$ t. (2007) [Encyclopedic Dictionary of Azerbaijan Toponymy: In 2 Volumes]. Pod red. R. Aliyevoi. T. 2. 84 p. Baku, Shark-Garb. (In Russian)

Gariaev, R. N. (2009). Etimologiia toponimicheskogo termina Kyrla $i$ toponima Kyrlai [Etymology of the Toponymic Term Kyrla and the Toponym Kyrlai]. Tenishevskiye chteniia. Sbornik nauchnykh statei. 388 p. Kazan', TGGPU. (In Russian)

Gafarova, F. F. (2009). Sravnitel'no-istoricheskaia kharakteristika nazvaniia saban [Comparative Historical Characteristics of the Name Saban]. Tenishevskie chteniia. Sbornik nauchnykh statei. 388 p. Kazan', TGGPU. (In Russian)

Geibullaev, G. A. (1986). Toponimiia Azerbaidzhana [Toponymy of Azerbaijan]. 198 p. Baku. Izd-vo Elm. (In Russian)

Gulieva, L. G. (1990). Tipologiia semanticheskoi struktury toponimikonov raznosistemnykh iazykov (na materiale toponimii Azerbaidzhana) [Typology of the Semantic Structure of Toponymicons of Different-
System Languages (based on Azerbaijan toponymy)]. 204 p. Baku. (In Russian)

Kamalov, A. A. (1994). Bashkir toponimi [Bashkir Toponymy]. 302 p. Ufa, Kitap. (In Russian)

Kavkazskii kalendar' na 1856 god, 1855. 353 s. (1994) [Caucasian Calendar for 1856, 1855. 353 p.]. (In Russian)

Khadieva, G. K. (2004). Oikonimi perioda Kazanskogo khanstva (po pistsovym knigam) [Oikonyms of the Kazan Khanate Period (According to Scribes)]. 196 p. Kazan'. (In Russian)

Kulakovskii, A. Ye. (2012). Pis'mo iakutskoi intelligentsii [A Letter to the Yakut Intelligentsia]. 189 p. Novosibirsk, "Nauka". (In Russian)

Murzaev, E. M. (1996). Tiurkskie geograficheskie nazvaniia [Türkic Geographical Names]. 254 p. Moscow, izdatel'skaia firma "Vostochnaia literatura" RAN. (In Russian)

Pletneva, S. A. (1973). Drevnosti chernykh klobukov [Antiquities of Black Cowls]. Svod arkheologicheskikh istochnikov. 96 p. Moscow, Nauka. (In Russian)

Rakhmani, A. A. (1987). Azerbaidzhan: granitsy $i$ administrativnoe delenie $v$ kontse XVI- XVIII $v v$. [Azerbaijan: Borders and Administrative Division in the Late $16^{\text {th }}-18^{\text {th }}$ Centuries]. Istoricheskaia geografiia Azerbaidzhana. Pp. 120-128. Baku, Elm. (In Russian)

Rashid-ad-din. Sbornik letopisei [Collection of Chronicles]. URL: http://www.vostlit.info/Texts/rus16/ Rasidaddin_2/framepred.html (accessed: 24.05.2021). (In Russian)

Rybal'chenko, T. Ye. (2009). Turetsko-russkii $i$ russko-turetskii slovar' [Turkish-Russian and RussianTurkish Dictionary]. 694 p. Moscow, Russkii iazyk. Drofa. (In Russian)

Sattarov, G. F. (1990). Tatar Antroponimikasy [Tatar Anthroponymics]. 278 p. Kazan, Kazan universitety nəshriiaty. (In Tatar)

\title{
ТОПОНИМИЧЕСКИЕ ПАРАЛЛЕЛИ ТАТАРСТАНА И АЗЕРБАЙДЖАНА
}

\author{
Арзу Идрис гызы Гусейнова, \\ Институт языкознания имени Насими \\ Национальной Академии наук Азербайджана, \\ Азербайджан, г. Баку, ул. Гусейна Джавида, д. 31, \\ arzu_56@mail.ru. \\ Гульфия Камиловна Хадиева, \\ Казанский федеральный университет, \\ Россия, 420008, г. Казань, ул. Кремлевская, д. 18, \\ gul-khadieva@yandex.ru.
}

В статье рассматриваются параллельные тюркские топонимы, встречающиеся на территориях Татарстана, Азербайджана, которые могут пролить свет на историю расселения тюркоя- 
зычных народов на огромных территориях, ареал распространения которых актуален в наше время, выясняются процессы формирования и происхождения топонимов за большой исторический период. Каждый хотел бы мысленно совершить путешествие к историческим истокам своего народа, ведь топонимы - это культурное наследие народов. Параллельные топонимы, как пазлы, помогают воссозданию картины расселения и формирования таких народов, как азербайджанцы, татары, башкиры, киргизы, кумыки и т. д. Дальнейшие исследования параллельных топонимов помогут получить ответ на многие вопросы ономастики. Рассматриваемые топонимические факты доказывают сложность миграционных путей и передвижений тюркских народов в ходе глобальных исторических процессов на огромных территориях.

Ключевые слова: параллельные этнотопонимы, бинарные корреляты, семантическое поле, лексема, аффикс множественности, глобальный.

Современная тюркская топонимика располагает богатым фактическим материалом по различным его разновидностям, теоретическим и методологическим потенциалом, основанном на достижениях общей лингвистики и ономастики. Во многом это связано с широким распространением тюркских названий на обширном геопространстве Евразии. Ареал распространения тюркских топонимических названий достаточно велик и тянется «на север до берегов Северного Ледовитого океана, на восток до Забайкалья и Большого Хингана, на запад до Восточной и Южной Европы, на юг до Тибета, Индии, Каракорума и Северной Африки» [Мурзаев, с. 37].

Объектом исследования данной статьи являются параллельные топонимы Татарстана и Азербайджана.

Тюркские топонимические параллели встречаются на огромной бескрайней территории, населенной различными тюркоязычными народами. В «Джами-ат-таварих» Фазлаллаха Рашидаддина сказано о племени татар следующее: «Их имя издревле было известно в мире. От них отделились многочисленные ветви. Все то племя <состояло $>$ из семидесяти тысяч домов <или семей>. Из-за $<$ их $>$ чрезвычайного величия и почетного положения другие тюркские роды, при $<$ всем> различии их разрядов и названий, стали известны под их именем и все назывались татарами» [Рашид-ад-дин].

Тюркская топонимическая система имеет свои общие закономерности, которые отмечались и отмечаются многими исследователями топонимии тюркоязычных регионов. Так, Л. Г. Гулиева отмечает, что «наличие в языках параллельных имен для одного объекта, а также имен бинарной оппозиции для разных объектов является ономастической универсалией» [Гулиева, с. 175].

В топонимии Татарстана так же, как и на территории других тюркоязычных регионов, встречаются бинарные корреляты. Такое явле- ние в топонимии встречается довольно часто. Перенос названия с одного объекта на другой это универсальный способ образования новых наименований в ойконимии любого языка.

Новый компонент ойконимов вносил определенную информацию о месте возникновения, размерах населенного пункта. Например: Oль Көек (Большой Куюк), Кече Көек (Малый Куюк), Югары Мәтәскә (Верхняя Метеска), ТҮбән Мәтаскә (Нижняя Метеска). От основной деревни со временем отделяются новые села, которые обычно называются так же, как основная деревня, но с прибавлением определяющих слов: иске 'старый', урта 'средний', оль 'большой' - кече 'малый', 'меньший', түбән 'нижний' - югары 'верхний'. Пары со словами югары - түбән, оль - кече состоят из лексем, которые активно употребляются в ойконимии Татарстана. «Причина этого явления кроется в сущности ойконимии. Одна из особенностей заключается в том, что в ней существуют базовые ойконимические объекты, которые могут служить основой для образования нового объекта, или материнские и дочерние» [Камалов, с. 98]. Базовые деревни в период образования дочерних населенных пунктов в социальной и экономической системе региона занимали важное место.

Среди ориентационных эпитетов преобладают югары, түбән, которые принадлежат к числу наиболее популярных пространственных

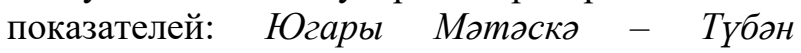
Мәтәскә, Югары Әйшә - Түбән Әйшә, Югары Am - Түбан Ambl.

Своеобразные коррелятивные пары образуют ойконимы типа Иске Кырлай - Кече Kырлай, Оль Мәңгәр - Кече Мәңгәр, Оль Мәтәскә - Югары Матаска, Иске Муй - Кече Муй, Иске Шырдан - Оль Шырдан, которые также являются элементами бинарной оппозиции, первые их компоненты нельзя противопоставить друг другу. В кратком справочнике «Административно-территориальное деление РТ» (1992) 
приводится 110 названий со словом яңза. В ойконимии региона отмечаются оппозиции в паре с нулевой формой. Это объясняется местом базового селения в социально-экономической жизни определенной территории: Зур Елга Елга, Иске Төбәк - Төбәк. Представляют интерес названия с базовым ойконимом. Эти ойконимы привели к появлению новых компонентов: Казиле = Югары Казиле - Урта Казиле ТҮбән Казиле; Әйшә = Югары Әйшә - Урта Әйшә - ТҮбән Әйшә.

Понятия югары 'верхний', урта 'средний', түбән 'нижний' в составе ойконимов служат ориентиром в пространстве в вертикальном отношении. Ближайшим от места ориентира считается объект, обозначенный понятием «нижний» - түбән, а дальним пунктом - объект, выраженный понятием «верхний»- югары. Причина, видимо, состоит в том, что одни объекты, расположенные в нижней части рек, гор и т. п., были освоены раньше территорий, расположенных в их верхней части и с маршрутным (по течению реки) освоением пространства [Хадиева, с. 181-182].

В топонимии Азербайджана также широко распространены бинарные корреляты, приведем примеры употребления бинарных коррелятов Агстафинского и Газахского районов Азербайджана, образованных с помощью компонентов yuxarl 'верхний', aşağı 'нижний', orta 'средний': Yuxarl Salahlı, Aşağı Salahl, Orta Salahll.

Г. Ф. Саттаров отмечал в Апастовском районе Татарстана деревню Иске Әнәле (Старые Енали), этимологию которого связывал со словом инал, означающим сословие знатных тюрков. По мнению ученого, местное произношение слова инал (апастовский диалект), әнәле <инәл иле> инәлле> әнәле; для среднего диалекта татарского языка характерен переход гласных и $>$ ә. В подтверждение своей гипотезы Г. Ф. Саттаров приводит и такой факт: около деревни Тархан в Тетюшском районе был найден могильный камень, датированный 1320 годом, принадлежащий булгарину Мир-Ибрагим Иналу. Исследователем приводятся примеры из Древнетюркского словаря: inal öz, inal quç, terbi inal, inal qayan [Саттаров, с. 86].

На территории Агстафинского района Азербайджана имеется село Эйналльы. В сочинении средневекового летописца Искендера Мюнши «Тарих-е-алем арай-и Аббаси» перечисляются азербайджанские племена средневековья: племя Абдаллу, одно из разветвлений известного Кызылбашского племени Шамлу, имевшее олке (ölkə) в Мугане, племя Иналлу другая ветвь Шамлу, имевшее олке поблизости от Ардебила, Шагаги [Рахмани, с. 121]. После распада сельджукского государства на территории Малой Азии стали известны племена инал, караман, зулькадар, таракли, багадурльь, шамлу. Таким образом, с миграцией огузских племен появились огузские топонимы на больших территориях. На территории Южного Азербайджана в Иране сохранился топоним Aйналль. Якутский просветитель, родоначальник якутской литературы А. Е. Кулаковский в работе «Письмо якутской интеллигенции» еще в 1912 году отмечал численность айналлинцев, проживающих в Якутской области: «<...> айналар - 1130 человек» [Кулаковский, с. 117].

Б. А. Будагов приводит факт существования топонима Айналлы в западном Азербайджане из «Кавказского календаря»: село Айналлы, входившее в четвертый милицейский участок Эчмиадзинского уезда, было разграблено и разрушено армянами в 1918 году [Budaqov, c. 154].

В Джебраильском, Губадлинском, Зангеланском районах Нагорного Карабаха Республики Азербайджан встречается ойконим Taтap - Tatar в названии многих сел, который отражает в себе тюркские племена татар. В Бардинском районе была деревня Татаркенд (Tatarkənd). Во многих районах Азербайджана сохранились сложные топонимы, образованные с помощью этнонима татар. Например, в Лачинском районе имеются топонимы Татарская скала (Tatar qaya) в селе Хагназар и Татарская летовка (Tatarlılar yaylağı) в селе Алхаслы. В Джебраильском районе встречается топоним Татарская равнина (Tatar düzӥ) в селе Нюсюс (Nüsüs). В Зангеланском районе в селе Вежнали есть топоним Taтарское ущелье (Tatar darəsi). В Гахском районе в деревне Армудлу есть $T a$ тарская скала (Tatar qaya). В Сальянском районе есть грязевой вулкан Татармехле (Tatarməhla). В Нефтчалинском районе имеется ойконим с таким названием. В Шамкирском районе ойконим Taтарль (Tatarl).

Этнотопоним Каратун, сохранившийся в названии железнодорожной станции и поселка в Татарстане, имеет свою параллель в Азербайджане - село Карадонлу, расположенное в Муганьской степи, которое до 1938 года было районным центром. В километре к северо-востоку от села находятся поселения, относящиеся к IX-XIII векам н.э. Поселение Каратун в Татарстане было известно с 1647 года как Еналеево и 
было основано в XVIII веке. По одной из версий, этимология топонима восходит к словам кара 'черный', тун 'платье, риза монаха, одеяние огнепоклонников'. Среди тюркских племен часто встречались племена, получившие название по цвету головных уборов и одежде. Например, карапапахлылар - название одного из племен в Азербайджане. Название тюркского народа каракалпаки также можно отнести к таким названиям. Впервые в Ипатьевской летописи 1146 и 1193 годов были упомянуты черные клобуки, которые принимали активное участие в жизни Киевской Руси, чему служит свидетельством повторяющееся в этой летописи устойчивое выражение «вся земля Руськая и чорные клобуки» [Плетнева, с. 24]. Из этого следует, что черные клобуки являлись важной военной силой киевских князей.

Интересно отметить, что топоним Кырлай встречается не только на территории проживания тюркских народов. В тюркоязычной литературе и эпосе отражаются многие топонимы. Топонимы - зеркальное отражение лирической души народа, его чаяний. В казахском эпосе «Кобланды-батыр» даются названия эпических городов Кырлы-Кала, Сырлы-Кала: «Города Кырлы-Кала и Сырлы-Кала силою взяв, хан Казан так хвастливо говорил: „Посмотрите, как укреплен город Кырлы-Кала. К городу моему Кырлы-Кала ни за что не подступится враг“"».

Яңңа Кырлай (Новый Кырлай) - село в Арском районе республики Татарстан. К этим топонимам добавим топоним Kырылыль (Qtrlli) Агстафинского района Республики Азербайджан, название одного из древних сел Азербайджана. На территории села находится Холм ворон (Qarğalar Tәрәsi), стоянка первобытных людей. Основными занятиями жителей села являются земледелие и скотоводство. Топоним Кырланенbl-Kırlannar (офиц. Котовское) - название гагаузского села на реке Ялпуг в Молдове. Первые тексты на гагаузском языке были собраны В. А. Мошковым, координатором общества археологии, истории и этнографии при императорском Казанском университете («Гагаузы Бендерского уезда», этнографические очерки и материалы).

Рассмотрим этимологию топонима Кырлай и топонимического термина Кырла в одноименной статье исследователя Р. Н. Гаряева, по мнению которого «остатки афф. -ла / -лә сохранились в татарских и башкирских терминах кырла 'гребни гор', йайла 'плоскогорья' и в топонимическом названии Озын кырла (название продолговатой горы с четырьмя гребнями в Гафурском районе Республики Башкортостан). В заключение Р. Н. Гаряевым выдвинуто предположение об аффиксе множественности -ла в ойкониме Кырлай, «состоящем из древнего общеалтайского показателя собирательной множественности -л и показателя неопределенной множественности - $a \gg$ [Гаряев, с. 112].

Этнотопоним Сабанча (Сабанчы) - поселок находился на территории современного Алексеевского района Республики Татарстан - в справочнике 1986 года не упоминается. Азербайджанский историк Г. А. Гейбуллаев отмечает множество топонимов Сабунчи в Азербайджане: гора Сабунчу, развалины Сабунчу в Западном Азербайджане, зимовка в Карсской области в Турции. Ученый ссылается на указ 1704 года персидского шаха Султана Гусейна (16941722), в котором среди перечисленных 36 тюркских племен отмечалось племя Сабунчу [Гейбуллаев, с. 60]. Сабунчи - поселок городского типа на Апшеронском полуострове. Сабунчинский район - один из 12 административных районов города Баку. В XVIII веке село Сабунчи было во владении сардара Ашур-бека Афшара, родоначальника азербайджанского дворянского рода Ашурбековых. Касаясь этимологии топонима Сабан, обратимся к работам исследователей. Как известно из исследования Ф. Ф. Гафаровой, слово сабан имеет широкое семантическое поле с основным значением во всех источниках - плуг. Перечислим шесть значений слова сабан в некоторых тюркских языках: татарском, башкирском, кумыкском, киргизском: 1) плуг; 2) устойчивые выражения, $c a-$ бан жир / пахотная земля /; 3) в киргизском пашня / сабан салуу - заниматься земледелием /, пашня; 4) в кабардино-балкарском будай сабанла - пшеничное поле; 5) весенние полевые работы / сабан чәчүе - весенний сев; 6) в тат. языке яровой / сабан ашлыгы - яровой хлеб, сабан урагы - жатва яровых [Гафарова, с. 90]. В «Турецко-русском словаре» слово saban переводится как плуг, kara saban - coxa [Рыбальченко, с. 255]. Можно предположить, что поселение земледельцев, пахарей называлось Сабанча в Татарстане и Сабунчи-Сабунчу в Азербайджане. С 1825 года Сабунчи становится одним из основных районов нефтедобычи на Абшероне, где в конце XIX и в начале XX века в связи с бурным развитием нефтяной промышленности в регионе отмечался большой прилив рабочих из разных мест огромной Российской империи, среди которых были и выходцы из По- 
волжья, в том числе татары, чьи потомки проживают и сейчас в Республике Азербайджан. С 1724 года Баку также стал заселяться казанскими татарами, черемисами, чувашами - в общей сложности около пяти тысяч человек, высланных в Баку на судостроительные работы.

На территории Азербайджана и Татарстана встречаются топонимы Акташ - Агдаш, Ляки. Акташ - село в Альметьевском районе Республики Татарстан, которое возникло триста лет назад. Село Акташ встречается и в Улаганском районе Республики Алтай Российской Федерации. Село Ляки находится на левом берегу реки Иганя в Сармановском районе Татарстана, известно с 1691 года. В начале XX века в селе Ляки функционировали церковь, земская школа и водяная мельница.

В Агдашском районе Азербайджана имеется железнодорожная станция и поселок Ляки (Laki). По данным «Кавказского календаря на 1856 год», Ляки являлось селом Агдашского магала, население которого обозначалось как татары-сунниты [Кавказский календарь на 1856 год, с. 353]. Так называлось тюркское население Азербайджана в XIX веке в Российской империи. В 1883 году на территории села была открыта железнодорожная станция, названная Ляки. Кроме поселка Ляки, существовали еще села Юхары Ляки (Верхние Ляки), Ашагы Ляки (Нижние Ляки), Орта Ляки (Средние Ляки). В азербайджанском языке для обозначения нижнее употребляется компонент amazbl, в отличие от татарского языка, где употребляется компонент түбан. По некоторым исследованиям, этимология топонима Ляки восходит к огузскому племени ляк [Энциклопедический словарь топонимики Азербайджана, с. 84].

По нашему мнению, многие параллельные топонимы и этнотопонимы, включая Иске Әнәле (Старые Енали), Каратун, Сабанча, Кьрлай, Акташ-Агдаш, Ляки Республики Татарстан, и их параллели, встречающиеся в Башкортостане, Азербайджане, Южном Азербайджане (Иран), Западной Сибири, Турции и других регионах, являются фактами сложных этнических процессов, связанных с передвижением и миграцией тюркских племен в различные исторические периоды. Параллельные тюркские топонимы, широко распространенные на территории Евразии и Малой Азии, свидетельствуют о том, что тюркские народы, проживающие в разные исторические периоды, занимались государственной деятельностью, вели торговлю, принимали активное участие в жизни этих регионов.

Таким образом, топонимические параллели, встречающиеся на разных территориях, несут в себе важнейшую информацию о народах, населяющих тот или иной регион. Подобные названия возникают не случайно, дальнее и ближнее родство их не вызывает сомнения, ибо народы, привыкшие к наименованиям определенной модели, определенного звучания, переносят их с собой, оставляя на новой территории. В них кроется историческая связь народов в разные эпохи.

\section{Литература}

Гаряев Р. Н. Этимология топонимического термина Кырла и топонима Кырлай // Тенишевские чтения - 2009: Сборник научных статей. Казань: ТГГПУ, 2009. $388 \mathrm{c.}$

Гафарова Ф. Ф. Сравнительно-историческая характеристика названия сабан // Тенишевские чтения - 2009: Сборник научных статей. Казань: ТГГПУ, 2009. 388 c.

Гейбуллаев Г. А. Топонимия Азербайджана. Баку. Изд-во: Элм, 1986. 198 с.

Гулиева Л. Г. Типология семантической структуры топонимиконов разносистемных языков (на материале топонимии Азербайджана). Баку, 1990. 204 c.

Кавказский календарь на 1856 год, 1855. 353 с.

Камалов А. А. Башкирская топонимия. Уфа: Китап, 1994. 302 с.

Кулаковский A. Е. Письмо якутской интеллигенции. Новосибирск: «Наука», 2012. 189 с.

Мурзаев Э. M. Тюркские географические названия. М.: Издательская фирма «Восточная литература» РАН, 1996. 254 с.

Плетнева С. А. Древности черных клобуков // Свод археологических источников. М.: Наука, 1973. $96 \mathrm{c}$.

Рахмани A. А. Азербайджан: границы и административное деление в конце XVI- XVIII вв. // Историческая география Азербайджана. Баку: Элм, 1987. C. $120-128$.

Рашид-ад-дин. Сборник летописей. URL: http://www.vostlit.info/Texts/rus16/Rasidaddin_2/frame pred.html (дата обращения: 24.05.2021).

Рыбальченко T. E. Турецко-русский и русскотурецкий словарь. М.: Русский язык. Дрофа, 2009. $694 \mathrm{c}$.

Саттаров Г. Ф. Татар антропонимикасы. Казан: Казан университеты нәшрияты. 1990, 278 с.

Хадиева $Г$. К. Ойконимы периода Казанского ханства (по писцовым книгам). Казань, 2004. 196 с.

Энциклопедический словарь топонимики Азербайджана: в 2 т. / под ред. Р. Алиевой. Баку: ШаркГарб, 2007. Т. 2.84 с. 
Budaqov B. Ә. Qeybullayev Q.Ә. Ermənistanda «Nafta-Press», 1998. $452 \mathrm{~s}$. Azərbaycan mənşəli toponimlərinin izahlı lüğəti. Bakı:

\title{
ТАТАРСТАН ҺӘМ АЗӘРБАЙЖАННЫН ТОПОНИМИК ПАРАЛЛЕЛЬЛӘРЕ
}

\author{
Арзу Идрис кызы Гусейнова, \\ Азәрбайжан Милли Фәннәр академиясенең \\ Насими исемендәге тел белеме институты, \\ Азәрбайжан, AZ1141, Баку ш., Гусейн Джавид ур., 31 нче йорт, \\ arzu_56@mail.ru. \\ Гөлфия Камиловна һадиева, \\ Казан федераль университеты, \\ Россия, 420008, Казан ш., Кремль ур., 18 нче йорт, \\ khadieva@yandex.ru.
}

\begin{abstract}
Мәкаләдә Татарстан һәм Азәрбайжан территорияләрендә очрый торган параллель төрки топонимнар тикшерелә. Алар төрки телле халыкларның гаять зур территорияләрдә урнашу тарихына ачыклык кертә ала. Мәкаләдә зур тарихи чор дәвамында топонимнарның формалашу hәм килеп чыгышы процесслары ачыклана. Топонимнар - ул халыкларның мәдәни мирасы, шуңа күрә һәркем үз халкының тарихи чыганакларын белергә тели. Параллель топонимнар азәрбайжан, татар, башкорт, кыргыз, кумык һ.б. халыкларның таралу һәм формалашу тарихын торгызырга ярдәм итә. Параллель топонимнарны алга таба тикшерүләр күп кенә ономастик сорауларга ачыклык кертәчәк. Тикшерелә торган топонимик фактлар гаять зур территорияләрдә глобаль тарихи процесслар барышында төрки халыкларның миграция юлларының катлаулылыгын һәм хәрәкәт итүләрен дәлилли.
\end{abstract}

Төп төшенчәләр: параллель этнотопонимнар, бинар коррелятлар, семантик кыр, лексема, күплек сан аффиксы, глобаль. 